(C) 2022, The Authors. Published by Elsevier Inc. and Fass Inc. on behalf of the American Dairy Science Association ${ }^{\circledR}$. This is an open access article under the CC BY license (http://creativecommons.org/licenses/by/4.0/).

\title{
Effect of milk replacer feeding rate and frequency of preweaning dairy calves in the southeastern United States: Glucose metabolism
}

\author{
Ruth M. Orellana Rivas, ${ }^{1}$ Thalyane Rodrigues, ${ }^{1}$ Jordana da Silveira E. Sousa, ${ }^{1}$ Victor H. L. R. Melo, ${ }^{1}$ \\ Jing Gao, ${ }^{1}$ Diego Ferreira de Araújo, ${ }^{1}$ Juliana Goncalves de Souza, ${ }^{1}$ Thiago N. Marins, ${ }^{1}$ Pedro Melendez, ${ }^{2,3}$ \\ John K. Bernard, ${ }^{1}$ and Sha Tao ${ }^{1 *}$ \\ ${ }^{1}$ Department of Animal and Dairy Science, University of Georgia, Tifton 31793 \\ ${ }^{2}$ Department of Population Health, College of Veterinary Medicine, University of Georgia, Tifton 31793 \\ ${ }^{3}$ Tifton Veterinary Diagnostic and Investigational Laboratory, College of Veterinary Medicine, University of Georgia, Tifton 31793
}

\begin{abstract}
The objective of this experiment was to examine the effect of milk replacer (MR) feeding rate (FR) and frequency $(\mathrm{FF})$ on glucose metabolism before and after weaning during summer and winter in the subtropical climate of the southeastern United States. Holstein calves $(\mathrm{n}=48 /$ season) were enrolled at $8 \mathrm{~d}$ of age (DOA) in the summer (June to August, body weight $=40.6 \pm 0.7 \mathrm{~kg}$ ) and winter (November to January, body weight $=41.9 \pm 0.8 \mathrm{~kg}$ ). In each season, calves were randomly assigned to 1 of 4 treatments in a $2 \times$ 2 factorial arrangement including $2 \mathrm{FR}$ [0.65 (low) or $0.76 \mathrm{~kg}$ of solids/d (high) of a $26 \% \mathrm{CP}$ and $17 \%$ fat $\mathrm{MR}]$ and $2 \mathrm{FF}[2 \times(0700$ and $1600 \mathrm{~h})$ or $3 \times(0700$, 1600 , and $2200 \mathrm{~h}$ )]. Calves were managed similarly and housed in polyethylene hutches bedded with sand. Milk replacer $(12.5 \%)$ was fed based on treatments until 42 DOA when FR was reduced by half and offered $1 \times /$ d $(0700 \mathrm{~h})$ for $7 \mathrm{~d}$. Plasma was collected weekly at 1400 $\mathrm{h}$ for analyses of glucose and insulin concentrations in all calves. Pre- and postprandial glucose and insulin concentrations of a subset of calves $(n=10 /$ treatment per season) were measured on 20 DOA. A subset of calves $(\mathrm{n}=8 /$ treatment per season) was subjected to an intravenous glucose tolerance test (GTT) on 27 and $57 \mathrm{DOA}$ and insulin challenge on 28 and 58 DOA at $1030 \mathrm{~h}$. Average ambient temperature was $26.1 \pm$ $2.2^{\circ} \mathrm{C}$ in summer and $12.9 \pm 5.4^{\circ} \mathrm{C}$ in winter. During the preweaning period in both seasons, feeding high increased plasma glucose concentrations compared with low, and increasing FF reduced basal insulin concentrations. Compared with $2 \times$, feeding $3 \times$ did not affect postprandial glucose but lowered insulin in the summer, whereas in the winter, increased glucose from 30 to $180 \mathrm{~min}$ but lowered insulin from 240 to $420 \mathrm{~min}$
\end{abstract}

Received February 11, 2021.

Accepted May 11, 2021.

*Corresponding author: stao@uga.edu after MR feeding. Following GTT before weaning in both seasons, $3 \times$ reduced insulin increment and area under the curve compared with $2 \times$ without affecting glucose disposal. After weaning, treatment did not affect glucose disposal or insulin responses after GTT during winter, but calves fed $3 \times$ had faster glucose disposal and stronger insulin responses than $2 \times$ during summer. In both summer and winter, preweaned calves fed $3 \times$ had greater decrement and area under the curve of plasma glucose after insulin challenge, suggesting enhanced peripheral tissue insulin response compared with $2 \times$. This effect persisted after weaning only during summer. Increasing FR had no effect on metabolic responses in both seasons. In conclusion, increasing MR FF from 2 to 3 times per day reduced insulin secretion but enhanced insulin response on peripheral tissues of preweaned calves regardless of season.

Key words: milk replacer, season, calf, glucose metabolism

\section{INTRODUCTION}

Calves raised during summer have lower ADG partially due to reduced ME available for growth (Stull et al., 2008; Broucek et al., 2009). This is mainly because of the lower starter intake and the increased energy requirement for maintenance due to heat stress (Gebremedhin et al., 1981; Chaves, 2011). Increasing milk replacer (MR) feeding rate (FR) has been reported to improve ADG for preweaned dairy calves (Chapman et al., 2016; Hill et al., 2016) and, therefore, is a potential approach to improve calf growth during summer. Our preliminary study (Orellana Rivas et al., 2020) reported that calves fed $0.66 \mathrm{~kg}$ of $\mathrm{DM} / \mathrm{d}$ of a $\mathrm{MR}$ containing $26 \% \mathrm{CP}$ and $17 \%$ fat (26:17, as-fed basis) twice daily had greater preweaning ADG compared with calves fed $0.55 \mathrm{~kg}$ of DM/d a MR containing $20 \% \mathrm{CP}$ and $20 \%$ fat during summer. However, feeding more than $0.66 \mathrm{~kg}$ of $\mathrm{DM} / \mathrm{d}$ of the 26:17 MR did not support any additional increase in ADG and led to increased incidence of ab- 
omasal bloating (Orellana Rivas et al., 2020). One potential mechanism for this lack of improvement in body growth is the lower energy and nutrient utilization due to delayed abomasal emptying, which may result from increased meal size and slower gastric motility caused by heat stress (Orellana Rivas et al., 2020).

Altered glucose metabolism by MR FR and heat stress may also influence body growth. Previous research suggests that feeding larger quantities of MR increases insulin response without influencing glucose disposal after an intravenous glucose tolerance test (GTT, Bach et al., 2013a). Similarly, we observed that increasing MR FR during summer increased plasma insulin concentration but did not affect glucose concentration (Orellana Rivas et al., 2020). These data suggest that increasing MR FR stimulates insulin release and possibly reduced insulin responsiveness on peripheral tissues, lowering the efficiency of glucose utilization by muscle and adipose tissue. These effects may also be exaggerated by heat stress during summer, leading to lower growth efficiency. Indeed, Tao et al. (2014) and Monteiro et al. (2016) reported that calves born to late gestation heat-stressed cows had increased glucose utilization by tissue other than muscle and adipose tissue.

Therefore, strategies need to be developed to minimize insulin resistance and improve glucose utilization by peripheral tissues when a large amount of MR is fed to preweaned calves, especially during summer. Increasing MR feeding frequency (FF) is reported to influence glucose metabolism. Increasing milk or MR FF to veal calves from $2 \times / d$ to $4-6 \times / d$ decreased plasma glucose and insulin concentrations after a meal (Kaufhold et al., 2000; Vicari et al., 2008). This suggested well-controlled postprandial hyperglycemia. However, if increased MR FF could improve calf growth partially by sensitizing insulin action on peripheral tissue has never been investigated under heat-stressed condition in the subtropical climate. Therefore, our hypothesis was that calves fed increased quantities of MR and raised during summer have blunted insulin action on peripheral tissues and that increasing MR FF will increase glucose partition to peripheral tissues by increasing peripheral tissue insulin responsiveness. The objective of this study was to evaluate the effect of MR FR and FF on glucose metabolism during pre- and postweaning periods of dairy calves in the summer and winter in the southeastern United States.

\section{MATERIALS AND METHODS}

\section{Animal Handling and Experimental Design}

The University of Georgia Institutional Animal Care and Use Committee approved the experimental design and animal handling before beginning the experiment. The experiment was conducted at the Dairy Research Center on the University of Georgia-Tifton Campus during the summer (May to October 2018) and the subsequent winter (November 2018 to April 2019). Detailed experimental procedures are reported in the companion paper (Orellana Rivas et al., 2022). Briefly, in each season, 48 Holstein calves were enrolled. After birth, all calves were fed a colostrum replacer containing at least $200 \mathrm{~g}$ of $\operatorname{IgG}$ (bovine $\mathrm{IgG}$ colostrum replacer, Land O'Lakes Inc.) and managed in the same manner according to the standard operating procedures of the dairy research center. The day of birth was considered as $1 \mathrm{~d}$ of the age (DOA). From 2 to 7 DOA, calves were fed $0.65 \mathrm{~kg}$ of $\mathrm{DM} / \mathrm{d}$ of a 26:17 MR (Provimi North America Inc.) twice daily (0700 and $1600 \mathrm{~h}$ ). The MR was composed of dried whey, dried milk protein, dried whey products, and vegetable and animal fat, and the actual $\mathrm{CP}$ and fat concentrations (of DM) were 27.98 and $19.01 \%$ during summer, and 26.22 and $18.37 \%$ in the winter. From 2 DOA, a textured calf starter $(18 \%$ CP, Godfrey's Warehouse Inc.) was offered ad libitum. At 8 DOA, calves were randomly assigned to 1 of 4 treatments in a $2 \times 2$ factorial arrangement, including 2 FR [0.65 (low) or 0.76 (high) $\mathrm{kg}$ of DM/d of the $26: 17$ $\mathrm{MR}]$ and $2 \mathrm{FF}[2 \times[0700$ and $1600 \mathrm{~h}]$ or $3 \times / \mathrm{d}(0700$, 1600 , and $2200 \mathrm{~h})]$. The FR (0.65 vs. $0.76 \mathrm{~kg}$ of DM/d) were selected based on our previous study. Orellana Rivas et al. (2020) reported that feeding $0.66 \mathrm{~kg}$ of $\mathrm{DM} / \mathrm{d}$ of a 26:17 MR improved ADG of preweaned calves raised in summer compared with those fed 0.55 $\mathrm{kg}$ of $\mathrm{DM} / \mathrm{d}$ a MR containing $20 \% \mathrm{CP}$ and $20 \%$ fat. However, further increasing FR from 0.66 to $0.77 \mathrm{~kg}$ of $\mathrm{DM} / \mathrm{d}$ of the 26:17 MR had no additional improvement in $\mathrm{ADG}$, and feeding an aggressive amount of MR (0.87 $\mathrm{kg}$ of $\mathrm{DM} / \mathrm{d}$ ) was associated with increased incidence of abomasal bloating (Orellana Rivas et al., 2020). The BW of calves at 8 DOA (before the treatments) averaged $40.6 \pm 0.7 \mathrm{~kg}$ in the summer and $41.9 \pm 0.8 \mathrm{~kg}$ in the winter, and was not different $(P>0.40)$ between treatments in either season. Calves were weaned by reducing the MR FR by half and fed once daily (0700 h) from 43 to 49 DOA. Calves remained on the experiment until 63 DOA. During the entire experiment, intake of $\mathrm{MR}$ and calf starter was recorded daily and BW was measured weekly. Water was offered ad libitum during the entire experiment. The water buckets were cleaned twice each day and refilled as needed. Investigators were not blinded to treatment information.

\section{Blood Sampling and Analyses}

Blood samples were collected from all calves at 1400 $\mathrm{h}$ on $7,14,21,28,35,42,49,56$, and 63 DOA from 
the jugular vein into sodium-heparinized Vacutainer tubes (Becton Dickinson) and immediately placed on ice. Samples were centrifuged at $1,700 \times g$ at $4^{\circ} \mathrm{C}$ for 30 min to collect plasma. Plasma concentrations of glucose (Autokit glucose, Wako Chemicals USA Inc.) and insulin (Bovine insulin ELISA, Mercodia AB) were determined using commercially available kits; the inter- and intraassay coefficients of variation were 4.2 and $8.2 \%$ for glucose, and 5.6 and $4.2 \%$ for insulin, respectively.

\section{Pre- and Postprandial Metabolism}

Pre- and postprandial glucose and insulin concentrations of a subset ( $\mathrm{n}=10 /$ treatment per season) of calves were measured at $20.1 \pm 1.3 \mathrm{DOA}$ (mean $\pm \mathrm{SD}$ ) during summer and at $20.2 \pm 1.2 \mathrm{DOA}$ during winter. On the day before sample collection, an indwelling jugular vein catheter (Terumo Corporation) was inserted $(\sim 1700 \mathrm{~h})$. Blood samples were collected through the catheter into Vacutainer tubes containing sodium fluoride and potassium oxalate (Becton Dickinson) at -15, 15, 30, 60, 90, $120,180,240,300$, and $420 \mathrm{~min}$ relative to the starting point of MR morning feeding $(0700 \mathrm{~h})$. Samples were immediately placed on ice and then centrifuged at 1,700 $\times g$ at $4^{\circ} \mathrm{C}$ for 30 min to obtain plasma. Plasma concentrations of glucose and insulin were analyzed using the same approaches described above. The inter- and intraassay coefficients of variation were 7.4 and $3.6 \%$ for glucose and 6.7 and $6.0 \%$ for insulin, respectively.

\section{Metabolic Tests}

A subset of calves ( $\mathrm{n}=8 /$ treatment per season) was subjected to GTT and insulin challenge (IC) during the pre- and postweaning periods. The maximal insulin concentration after a GTT $(41.5$ vs. $98.7 \mu \mathrm{U} / \mathrm{mL}, \mathrm{SD}$ $=26.3 \mu \mathrm{U} / \mathrm{mL}$, respectively) of calves fed 0.479 and $0.957 \mathrm{~kg} / \mathrm{d}$ MR (25:19; Bach et al., 2013a) were used to calculate the sample size. A sample size of 6 calves per treatment per season was calculated using a level of significance of 0.05 and $90 \%$ power. Therefore, 8 animals per treatment per season will provide enough power. At each period, GTT and IC were conducted on 2 adjacent days with GTT performed on the first day and IC on the following day. The actual day when GTT was performed was $26.9 \pm 1.1$ and $57.2 \pm 1.3$ DOA during summer and $27.3 \pm 1.1$ and $57.1 \pm 1.1 \mathrm{DOA}$ during winter. The IC was conducted on $27.9 \pm 1.1$ and $57.9 \pm$ 1.1 DOA during summer and $28.3 \pm 1.1$ and $58.1 \pm 1.1$ DOA during winter. On the day of GTT, immediately after MR feeding $(\sim 0730 \mathrm{~h})$, a catheter was inserted into the jugular vein of calves and remained until the end of IC on the following day. At $3.5 \mathrm{~h}$ following the morning MR feeding ( $\sim 1030 \mathrm{~h})$, calves received a bolus of glucose $[0.3 \mathrm{~g} / \mathrm{kg}$ of BW (Tao et al., 2014; Monteiro et al., 2016), dextrose 50\%, wt/vol; Phoenix Scientific Inc.] or insulin $[0.1 \mathrm{IU} / \mathrm{kg}$ of $\mathrm{BW}$ (Tao et al., 2014; Monteiro et al., 2016), Novolin R, $100 \mathrm{IU} / \mathrm{mL}$, recombinant human insulin, Novo Nordisk Inc.] through the catheter inserted in the jugular vein followed by $10 \mathrm{~mL}$ of sterile saline containing $10 \mathrm{IU} / \mathrm{mL}$ heparin to flush the catheter and prevent clotting. The first 2 to $3 \mathrm{~mL}$ of blood collected was discarded before each sample. Blood samples were collected through the catheter into Vacutainer tubes containing sodium fluoride and potassium oxalate (Becton Dickinson) at $-15,-5,0,5,10$, $15,20,30,40,50,60,75,90$, and $120 \mathrm{~min}$ relative to the glucose infusion during GTT, and at $-15,-5,0$, $15,20,30,40,50,60,75,90$, and $120 \mathrm{~min}$ relative to insulin infusion during IC. Immediately after sampling, blood tubes were placed on ice and then centrifuged at $1,700 \times g$ at $4^{\circ} \mathrm{C}$ for $30 \mathrm{~min}$ to collect plasma. Plasma concentrations of glucose and insulin were determined as described before. For samples collected during GTT, the inter- and intra-CV were 7.9 and $3.0 \%$ for glucose, and 6.8 and $4.9 \%$ for insulin, respectively. For samples collected during IC, the inter- and intraassay coefficients of variation were 3.3 and $6.2 \%$ for glucose, and 7.1 and $4.5 \%$ for insulin, respectively.

\section{Calculation and Statistical Analyses}

For data collected from metabolic tests, the average concentration of plasma glucose or insulin for the samples collected at $-15,-5$, and 0 min relative to infusion was considered as baseline. The baseline values were subtracted from the maximum or minimum concentrations to obtain the increment or decrement change in glucose or insulin concentrations when appropriate. The AUC between times was calculated using the trapezoidal method, where the concentrations of glucose or insulin were calculated by subtracting the baseline value from the actual glucose or insulin concentrations. The accumulated AUC of glucose and insulin were calculated from 5 to $30 \mathrm{~min}, 5$ to $60 \mathrm{~min}$, and 5 to $120 \mathrm{~min}$ for GTT, and from 15 to $30 \mathrm{~min}$, 15 to $60 \mathrm{~min}$, and 15 to $120 \mathrm{~min}$ for IC. Exponential curves of glucose concentration from 5 to $60 \mathrm{~min}$ of the GTT and from 15 to $40 \mathrm{~min}$ for the IC were fitted using PROC NLIN of SAS (SAS Institute Inc.), and the clearance rate $(\mathbf{C R})$ and time to reach half of the maximal concentration $\left(\mathbf{T}_{1 / 2}\right)$ were calculated using the following equations: $\mathrm{CR}, \% / \mathrm{min}=100 \times\left(\ln \left|\mathrm{t}_{\mathrm{a}}\right|\right.$ $\left.-\ln \left|t_{b}\right|\right) /\left(t_{b}-t_{a}\right) ;$ and $T_{1 / 2}$, min $=100 \times[\ln (2)] / C R$, where $\left|t_{a}\right|$ and $\left|t_{b}\right|$ are the concentrations at time $a$ and b, respectively (Hayirli et al., 2001). 
Basal and pre- and postprandial plasma concentrations of glucose and insulin were analyzed by PROC MIXED of SAS 9.4 as repeated measures data. The model included sex, FR, FF, time, and their interactions with calf within treatment $(\mathrm{FR} \times \mathrm{FF})$ as a random variable. Data collected from metabolic tests during pre- and postweaning periods were analyzed separately. Covariance structures of PROC MIXED models were selected based on goodness of fit criteria of SAS (Littell et al., 1998). The GLM procedure of SAS was used to analyze baseline, maximum, minimum, increment or decrement, CR, $\mathrm{T}_{1 / 2}$, and accumulated AUC of glucose and insulin in each test. The model included sex, FR, FF, and their interaction. Plasma concentrations of glucose and insulin during GTT and IC were analyzed as repeated measures data using PROC MIXED of SAS. The statistical model included sex, FR, FF, minute relative to infusion, and their interactions with calf within the treatment $(\mathrm{FR} \times \mathrm{FF})$ as the random variable. The least squares means \pm standard error of the means are reported. Significance and tendency were declared when $P \leq 0.05$ and $0.05<P \leq 0.10$, respectively.

\section{RESULTS}

\section{Environment, Intake, and Growth}

The detailed performance data were reported in the companion paper (Orellana Rivas et al., 2022). During summer and winter, average daily ambient temperature was $26.14 \pm 2.24^{\circ} \mathrm{C}$ and $12.85 \pm 5.42^{\circ} \mathrm{C}$ (mean \pm $\mathrm{SD}$ ), and relative humidity averaged $83.85 \pm 7.78 \%$ and $81.54 \pm 15.18 \%$, respectively. These data suggest that calves during summer were exposed to heat stress. In both seasons, feeding high increased $(P \leq 0.01)$ intake of MR compared with low supporting improved $(P=0.02)$ preweaning $\mathrm{BW}$ gain. Increased MR FR also resulted in greater $(P \leq 0.10)$ feed efficiency, as expressed by ADG/DMI, ADG/CP, or ADG/ME during the experimental period in both seasons. During summer, feeding MR $3 \times / \mathrm{d}$ supported greater intake of starter and DM at wk 8 and 9 of age compared with $2 \times / \mathrm{d}(\mathrm{FR} \times$ time: $P \leq 0.08)$. But MR FF did not affect ADG during the experimental period or BW gain before and after weaning during summer. In contrast, during winter, feeding MR more frequently supported greater $(P \leq 0.08)$ intake of starter, DMI, CP, and $\mathrm{ME}$, resulting in increased $(P \leq 0.08) \mathrm{ADG}$ and gains in BW during the entire experimental period. Additionally, feeding MR $3 \times / \mathrm{d}$ tended to support greater $(P=0.07)$ BW gain during the preweaning period compared with $2 \times /$ d during winter. Milk replacer FF did not affect efficiency measures in both seasons regardless of FR.

\section{Basal and Pre- and Postprandial Glucose and Insulin}

Preweaning plasma glucose concentration was higher $(P \leq 0.04)$ for calves fed high compared with low during both summer and winter (Table 1). However, MR FR did not affect $(P>0.15)$ plasma insulin concentration before weaning or circulating glucose or insulin concentrations after weaning. During the preweaning period, increasing $\mathrm{FF}$ from 2 to $3 \times / \mathrm{d}$ lowered $(P \leq$ 0.01) plasma insulin concentrations in both seasons without $(P \geq 0.17)$ affecting plasma glucose concentrations (Table 1). After weaning, calves previously fed $3 \times / d$ had higher $(P=0.03)$ plasma glucose concentrations compared with those previously fed $2 \times / \mathrm{d}$ only during winter (Table 1). Milk replacer FF had no effect $(P \geq 0.59)$ on plasma insulin concentrations after weaning in both seasons. Regardless of seasons, feeding MR more times increased $(P \leq 0.01)$ the ratio of glucose to insulin before weaning. However, FR did not $(P$ $\geq 0.40$ ) affect the ratio of glucose to insulin before and after weaning.

Pre- and postprandial glucose concentrations at $\sim 20$ DOA were not affected by FR in both seasons (FR $\times$ time: $P \geq 0.30$; Supplemental Table S1, Supplemental Figure S1A, S1C; https://doi.org/10.5281/zenodo .4613068, Orellana Rivas and Tao, 2021). No differences were observed for pre- and postprandial insulin concentrations due to FR during winter $(\mathrm{FR} \times$ time: $P=0.74 ;$ Supplemental Table S1), but calves fed high had higher $(P=0.04)$ plasma insulin concentrations at 15 min after MR feeding compared with those fed low during summer $(\mathrm{FR} \times$ time: $P=0.01$, Supplemental Figure S1B). Before MR feeding, calves fed $3 \times / \mathrm{d}$ had higher $(P \leq 0.03)$ plasma concentrations of glucose and insulin compared with those fed $2 \times / d$ in both seasons $($ FF $\times$ time: $P \leq 0.03$; Figure 1$)$. Feeding $3 \times / \mathrm{d}$ in the winter compared with $2 \times$ increased $(P \leq 0.07)$ plasma glucose concentrations from 30 to 180 min after MR feeding $(\mathrm{FF} \times$ time: $P=0.03$; Figure $1 \mathrm{C})$. In contrast, plasma insulin concentrations from 15 to 180 min were not different among FF but were lower $(P \leq 0.07)$ from 240 to $420 \mathrm{~min}$ for $3 \times / \mathrm{d}$ compared with $2 \times / \mathrm{d}$ after MR feeding $(\mathrm{FF} \times$ time: $P \leq 0.01$, Figure 1D). During the summer, feeding $3 \times / d$ did not affect postprandial glucose concentration, but reduced plasma insulin concentration from 30 to 420 min after MR feeding compared with $2 \times / \mathrm{d}(\mathrm{FF} \times$ time: $P<0.01$, Figure $1 \mathrm{~A}, 1 \mathrm{~B})$.

\section{Metabolic Tests}

During the preweaning period, $\mathrm{CR}, \mathrm{T}_{1 / 2}$, and AUC of glucose following GTT were not different $(P \geq 0.11)$ among treatments in either season except that calves fed low tended $(P=0.07)$ to have higher $\mathrm{AUC}_{30}$ than 
Table 1. Milk replacer (MR) feeding rate (FR) and frequency (FF) effects on basal plasma glucose and insulin concentrations during summer and winter

\begin{tabular}{|c|c|c|c|c|c|c|c|c|}
\hline \multirow{2}{*}{ Item } & \multicolumn{4}{|c|}{ Treatment $^{1}$} & \multirow{2}{*}{ SEM } & \multicolumn{3}{|c|}{$P$-value } \\
\hline & \multicolumn{2}{|c|}{ Low } & \multicolumn{2}{|c|}{ High } & & $\mathrm{FR}$ & $\mathrm{FF}$ & $\mathrm{FR} \times \mathrm{FH}$ \\
\hline \multicolumn{9}{|l|}{ Summer } \\
\hline \multicolumn{9}{|c|}{ Glucose, mg/dL } \\
\hline wk 1-6 & 86.9 & 83.1 & 93.3 & 89.6 & 2.7 & 0.02 & 0.17 & 0.98 \\
\hline \multicolumn{9}{|c|}{ Insulin, $\mu \mathrm{g} / \mathrm{L}$} \\
\hline wk $6-9$ & 0.31 & 0.29 & 0.23 & 0.28 & 0.04 & 0.16 & 0.59 & $\begin{array}{l}0.22 \\
0.30\end{array}$ \\
\hline \multicolumn{9}{|c|}{ Glucose/insulin } \\
\hline wk 1-6 & 26 & 501 & 307 & 622 & 51 & 0.51 & $<0.01$ & 0.24 \\
\hline wk 6-9 & 225 & 250 & 280 & 252 & 34 & 0.40 & 0.99 & 0.44 \\
\hline \multicolumn{9}{|l|}{ Winter } \\
\hline \multicolumn{9}{|c|}{ Glucose, $\mathrm{mg} / \mathrm{dL}$} \\
\hline \multicolumn{9}{|c|}{ Glucose/insulin } \\
\hline wk $1-6$ & 327 & 461 & 294 & 491 & 65 & 0.90 & 0.01 & 0.61 \\
\hline wk 6-9 & 234 & 318 & 292 & 233 & 36 & 0.75 & 0.77 & 0.06 \\
\hline
\end{tabular}

${ }^{1} \mathrm{Low}=0.65 \mathrm{~kg}$ of DM/d of a MR containing $26 \% \mathrm{CP}$ and $17 \%$ fat; high $=0.76 \mathrm{~kg}$ of DM $/ \mathrm{d}$ of a MR containing $26 \% \mathrm{CP}$ and $17 \%$ fat; $2 \times=$ feeding the MR twice a day $(0700$ and $1600 \mathrm{~h}) ; 3 \times=$ feeding the MR 3 times a day $(0700,1600$, and $2200 \mathrm{~h}) ; \mathrm{n}=12 /$ treatment per season.

those fed high during winter (Tables 2 and 3, Supplemental Figure S2, https://doi.org/10.5281/zenodo .4613068, Orellana Rivas and Tao, 2021). In response to intravenous glucose infusion, preweaned calves fed $3 \times / \mathrm{d}$ had lower $(P \leq 0.05)$ maximal concentration, increment, and AUC of plasma insulin compared with calves fed $2 \times / \mathrm{d}$ in both winter and summer (Tables 2 and 3, Figure 2B, 2D). After weaning, the response to GTT among treatments differed during summer and winter. In the winter, $\mathrm{FR}$ or $\mathrm{FF}$ did not affect $(P \geq$ 0.10) $\mathrm{CR}, \mathrm{T}_{1 / 2}$, and AUC of plasma glucose, or the increment and AUC of circulating insulin following GTT of postweaned calves (Table 3, Figure 3C, 3D, Supplemental Figure 3C, 3D, https://doi.org/10.5281/zenodo .4613068, Orellana Rivas and Tao, 2021). In contrast, during summer, calves previously fed $3 \times / \mathrm{d}$ tended $(P$ $=0.10)$ to have faster glucose $\mathrm{CR}$, greater $(P \leq 0.05)$ glucose $\mathrm{AUC}_{60}$ and $\mathrm{AUC}_{120}$, and higher $(P \leq 0.04)$ increment and AUC of circulating insulin compared with those previously fed $2 \times / \mathrm{d}$ (Table 2, Figure 3A, 3B). Milk replacer FR had no effect $(P \geq 0.11)$ on $\mathrm{CR}, \mathrm{T}_{1 / 2}$, and AUC of plasma glucose, or the increment and AUC of plasma insulin after GTT of postweaned calves during summer (Table 2, Supplemental Figure S3A, S3B).

During summer, treatment did not affect $(P \geq 0.07)$ insulin clearance after IC before weaning. After weaning in the summer, calves previously fed low $3 \times / \mathrm{d}$ had greater $(P<0.05) \mathrm{CR}$ but lower $\mathrm{T}_{1 / 2}$ than those fed low
$2 \times / \mathrm{d}$ with calves fed high intermediate $(\mathrm{FR} \times \mathrm{FF}: P \leq$ $0.02)$; however, treatment had no effect $(P>0.10)$ on insulin AUC after intravenous insulin infusion (Table 4). In the winter, FR, FF, or their interaction had no $(P \geq 0.09)$ effect on $\mathrm{CR}, \mathrm{T}_{1 / 2}$, and AUC of plasma insulin following IC before and after weaning (Table 5, Figure 4D and 5D, Supplemental Figure S4D and S5D, https://doi.org/10.5281/zenodo.4613068, Orellana Rivas and Tao, 2021). Compared with those fed $2 \times /$ d, preweaned calves fed $3 \times / \mathrm{d}$ had greater $(P \leq$ 0.03 ) decrement and AUC of plasma glucose after IC in both summer and winter (Tables 4 and 5, Figure $4 \mathrm{~A}, 4 \mathrm{C})$. During the postweaning period in the summer, calves previously fed $3 \times / \mathrm{d}$ had greater $(P=0.04)$ glucose $\mathrm{AUC}_{30}$ compared with those previously fed $2 \times / d$ (Table 4). Additionally, interactions of $\mathrm{FR}$ and FF $(P \leq 0.05)$ were observed for decrement, $\mathrm{AUC}_{60}$, and $\mathrm{AUC}_{120}$ of circulating glucose. These were because calves previously fed high $3 \times / d$ had the greatest values compared with other treatments (Table 5). In contrast, treatment did not $(P \geq 0.08)$ affect parameters related to glucose responses following IC of postweaned calves raised during winter.

\section{DISCUSSION}

Both nutrition and environment significantly affect an animal's metabolism, which might partially 

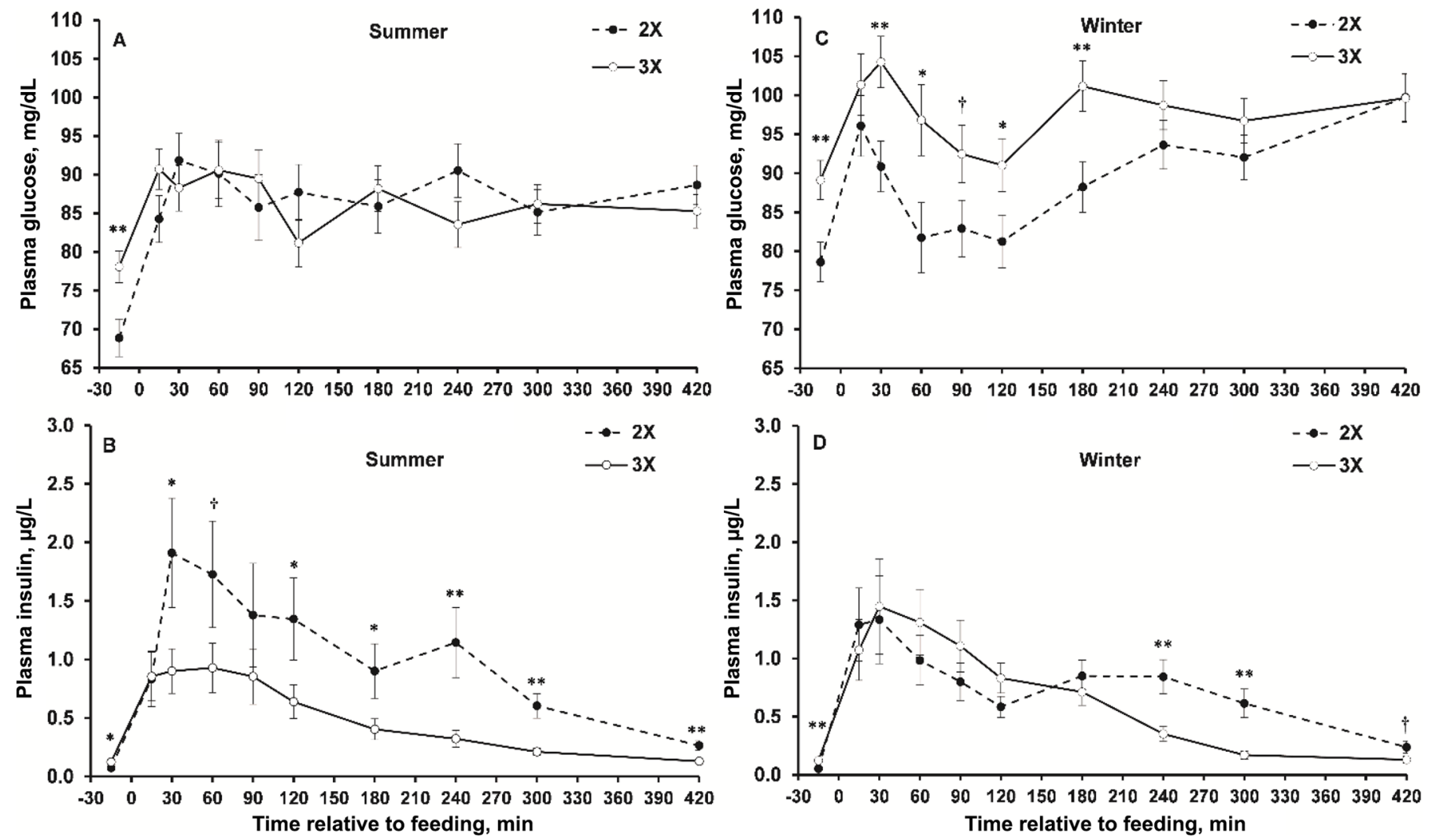

Figure 1. Effect of milk replacer feeding frequency [twice $(2 \times, \mathrm{n}=20)$ versus 3 times $(3 \times, \mathrm{n}=20)$ per $\mathrm{d}$ ] on plasma glucose and insulin concentrations relative to morning milk replacer feeding $(0700 \mathrm{~h})$ on $20.2 \pm 1.3 \mathrm{~d}$ of age during summer and $20.2 \pm 1.2 \mathrm{~d}$ of age during winter. Error bars represent SEM. ${ }^{* *} P \leq 0.01,{ }^{*} P \leq 0.05, \dagger P \leq 0.10$.

explain the responses in growth performance. In this current experiment, regardless of season, increasing FR increased basal plasma glucose concentration before weaning without affecting insulin concentration, possibly due to the higher lactose consumption with greater MR intake. In contrast, our previous study conducted in summer (Orellana Rivas et al., 2020) reported that calves fed high had similar plasma glucose and higher insulin concentrations compared with calves fed low. The discrepancy between studies may be due to the time of blood sample collection $[1400 \mathrm{~h}$ in this current study vs. $1100 \mathrm{~h}$ in Orellana Rivas et al. (2020) relative to the morning feeding ( $0700 \mathrm{~h}$ in both studies)]. Increasing $\mathrm{FF}$ from 2 to $3 \times / \mathrm{d}$ did not affect plasma glucose concentration but decreased circulating insulin concentrations during the preweaning period in both seasons. This, coupled with a higher glucose to insulin ratio, may suggest that feeding MR more frequently reduced insulin release and enhances peripheral tissue insulin responsiveness before weaning. Neither FR nor FF altered basal glucose and insulin concentrations after weaning during summer. In contrast, calves previously fed MR more frequently in the winter had greater plasma glucose concentrations after weaning. This may suggest increased hepatic gluconeogenesis, reduced glucose utilization, or both. However, because growth was not affected by treatment in both seasons, basal glucose concentrations do not seem to be associated with postweaning body growth in this experiment.

During the preweaning period in both seasons, calves fed $3 \times / d$ had similar glucose clearance but reduced insulin responses following GTT than those fed $2 \times / d$. These data indicate that increasing FF diminished pancreatic insulin release after glucose stimulation without affecting glucose disposal. Moreover, calves fed MR more frequently had stronger glucose responses following IC. This, coupled with similar insulin clearance, suggests that increasing $\mathrm{FF}$ enhanced insulin mediated glucose entry into the peripheral tissues, such as muscle and adipose tissues, of preweaned calves. This may be a negative feedback response to the reduced insulin release and explains similar glucose disposal after GTT between calves fed MR 2 and $3 \times /$ d. In addition, season did not affect these responses. In contrast, Stanley et al. (2002) reported that increasing FF from 1 to $2 \times / d$ increased insulin release in response to intravenous 
Orellana Rivas et al.: MILK REPLACER FEEDING RATE AND FREQUENCY ON METABOLISM






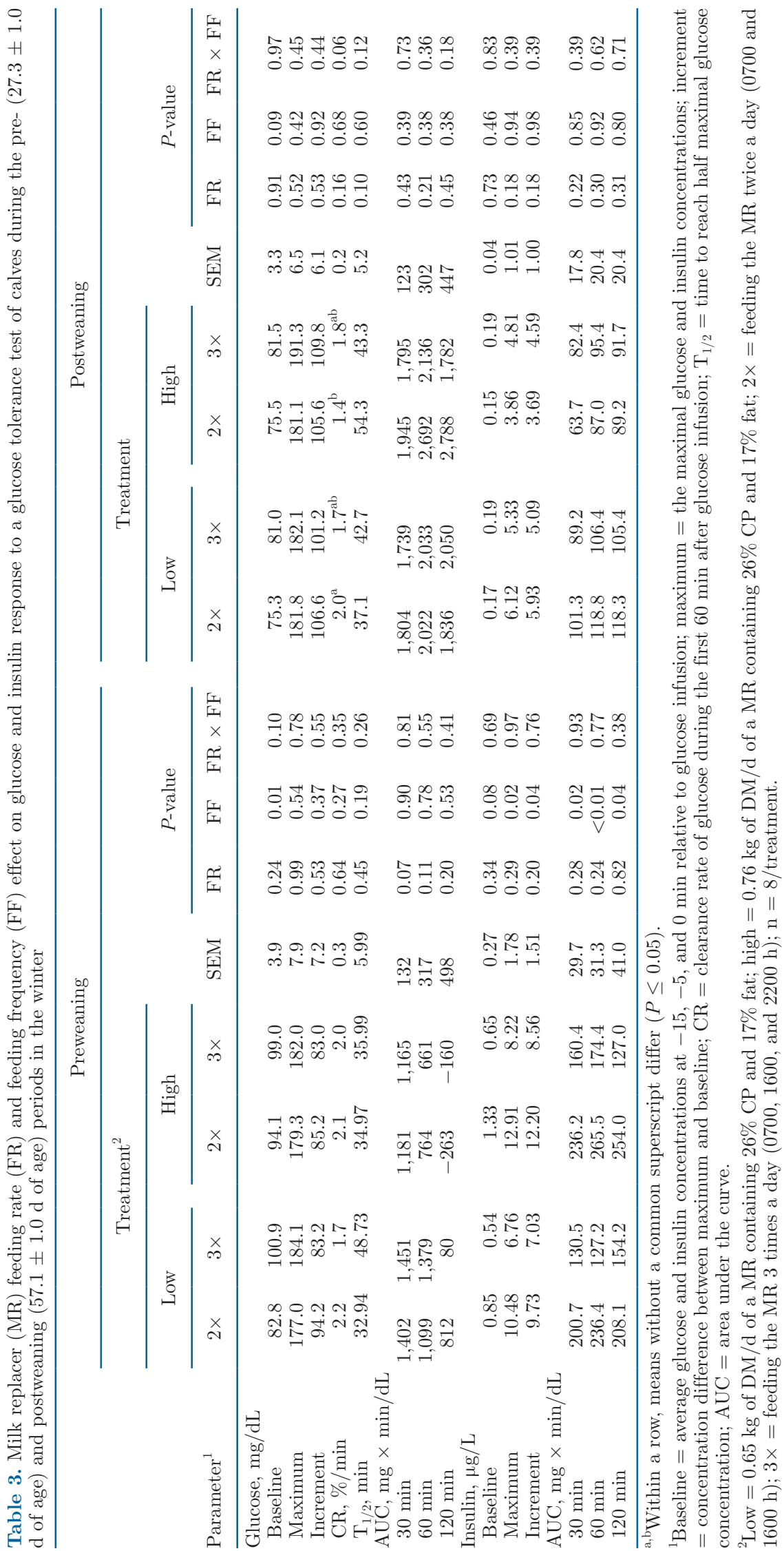


glucose infusion without influencing peripheral tissue insulin sensitivity. When raised on an automated calf feeder and fed larger quantities of MR $(1.2 \mathrm{~kg}$ solids of $\mathrm{MR} / \mathrm{d}$ containing $26 \% \mathrm{CP}$ and $18 \%$ fat), calves given MR access $4 \times / d$ had similar glucose clearance after GTT without influencing insulin secretion and tissue response compared with those given MR access $2 \times / \mathrm{d}$ (MacPherson et al., 2019). The reasons for the discrepancy among studies may include, but are not limited to, amount of MR offered, composition of MR, and feeding method.

Before the morning MR feeding in both seasons, calves fed $3 \times / d$ had higher plasma glucose concentrations due to the shorter interval from last MR feeding (9 vs. $15 \mathrm{~h}$, respectively) compared with calves fed $2 \times /$ d. This also explains the higher preprandial plasma insulin concentration observed for calves fed $3 \times / \mathrm{d}$ compared with those fed $2 \times /$ d. Similarly, MacPherson et al. (2019) reported higher preprandial plasma glucose concentrations for calves' given access $4 \times / d$ to an automated calf feeder compared with those at $2 \times / \mathrm{d}$. Al- though numerically higher in calves allowed MR more frequently, plasma insulin concentrations before feeding was not affected by FF (MacPherson et al., 2019). It is important to note that the number of animals per FF (5 vs. 20 ) in the experiment conducted by MacPherson et al. (2019) is lower than this current experiment.

The postprandial glucose metabolism of the milk-fed calves is also affected by FF. Compared with those fed $1 \times / d$, preweaned dairy calves fed MR $2 \times / d$ had similar postprandial plasma glucose concentrations but reduced insulin concentrations (Stanley et al., 2002). Similarly, MacPherson et al. (2019) reported that preweaned dairy calves raised on an automated calf feeder and allowed MR access $4 \times / \mathrm{d}$ had similar postprandial plasma glucose concentrations but lower insulin concentrations than those allowed MR access $2 \times / \mathrm{d}$ at wk 4 of age. In contrast, in large veal calves $(\mathrm{BW} \approx 110-140$ $\mathrm{kg}$ ), feeding milk or MR more frequently than $2 \times / \mathrm{d}$ was associated with reduced postprandial plasma glucose and insulin concentrations (Kaufhold et al., 2000; Vicari et al., 2008). The discrepancy between studies may
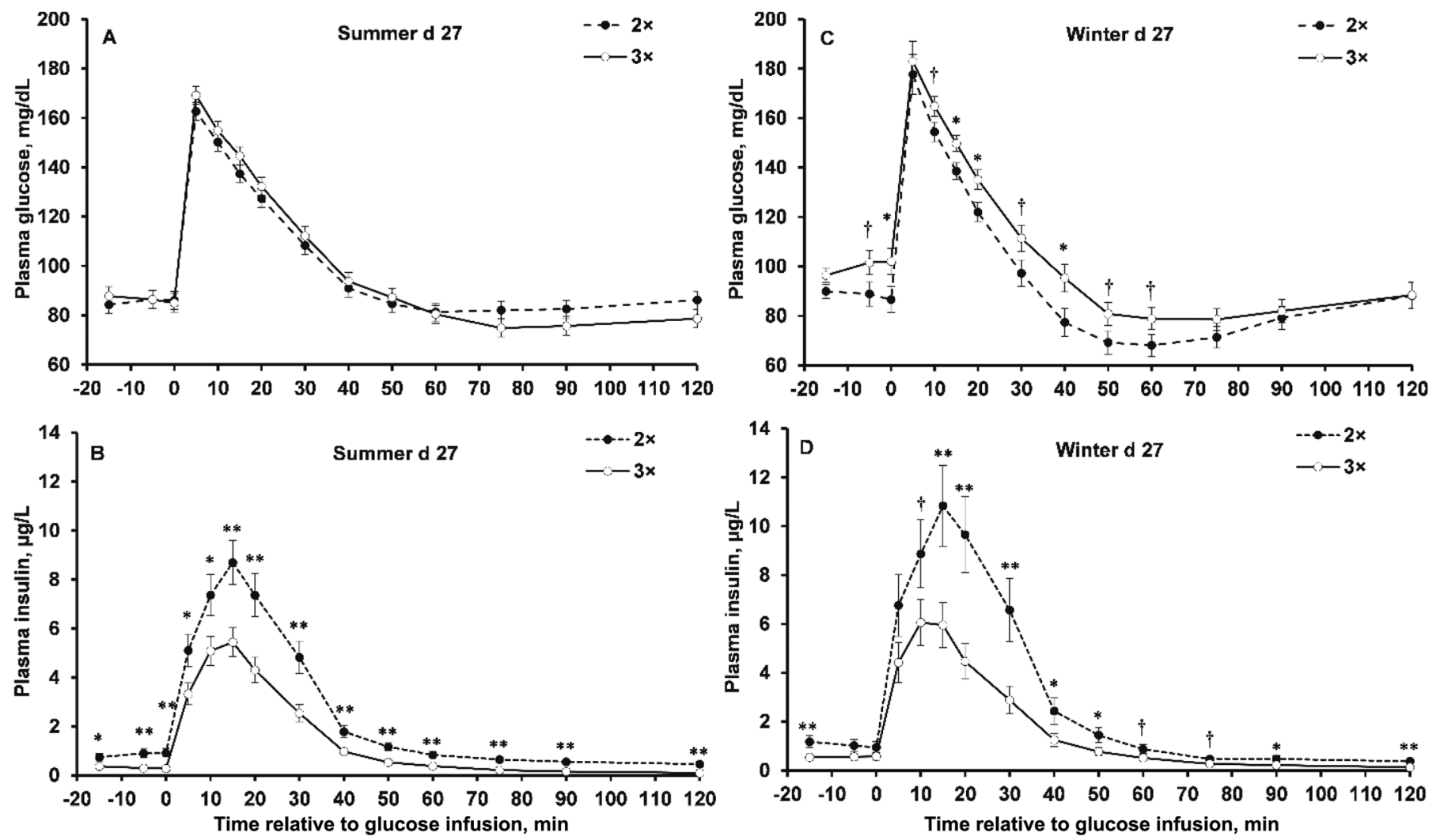

Figure 2. Effect of milk replacer feeding frequency [FF, twice $(2 \times, \mathrm{n}=16 /$ season $)$ versus 3 times $(3 \times, \mathrm{n}=16 /$ season $)$ per d] on plasma glucose and insulin concentrations during a glucose tolerance test performed on calves at $26.9 \pm 1.1 \mathrm{~d}$ of age during summer and $27.3 \pm 1.1 \mathrm{~d}$ of age during winter. Error bars represent SEM. During summer for the glucose concentration, effect of FF $(P=0.82)$ and FF by minute interaction $(P=0.24)$. During summer for the insulin concentration, effect of $\mathrm{FF}(P<0.01)$ and $\mathrm{FF}$ by minute interaction $(P<0.01)$. During winter for the glucose concentration, effect of FF $(P=0.05)$ and FF by minute interaction $(P=0.40)$. During winter for the insulin concentration, effect of FF $(P=0.01)$ and FF by minute interaction $(P=0.10)$. ${ }^{* *} P \leq 0.01,{ }^{*} P \leq 0.05, \dagger P \leq 0.10$. 
be due to the higher MR FR and older age (11-14 vs. 8 wk of age) of veal calves than preweaned dairy calves. Interestingly, in this current study, distinct patterns of postprandial circulating glucose and insulin concentration were observed between calves with different MR $\mathrm{FF}$ in different seasons.

During summer, calves with different FF had similar postprandial plasma glucose concentrations, consistent with results reported by Stanley et al. (2002) and MacPherson et al. (2019). However, calves fed MR more frequently had higher plasma glucose concentrations from 30 to 180 min after morning feeding during winter. This is particularly surprising because calves fed $3 \times / \mathrm{d}$ received less $\mathrm{MR}$, and thus lower lactose intake, per meal relative to calves fed $2 \times / \mathrm{d}$. Because no differences were observed for glucose disposal following GTT, the higher postprandial plasma glucose concentrations may suggest faster nutrient delivery to the small intestine and intestinal glucose absorption because of the faster abomasal emptying rate of calves fed MR more frequently in the winter. The reasons for the distinct patterns of postprandial plasma glucose concentration between FF in different seasons are not clear but may reflect the increased glucose usage for maintenance during heat stress. During lactation, heatstressed dairy cows had increased glucose utilization as an energy source in nonmammary gland tissues or cells (Baumgard and Rhoads, 2012). Additionally, previous studies (Tao et al., 2014; Monteiro et al., 2016) observed that maternal heat stress during the last 45 d of gestation increased glucose disposal after intravenous glucose infusion of the preweaned calf. Presumably, similar increases in glucose utilization by pre- and postnatal calves raised during summer would occur and mask potential differences in postprandial plasma glucose concentrations observed with different FF. Similar to glucose concentrations, postprandial plasma insulin concentrations displayed distinct patterns in calves fed 2 vs. $3 \times / d$ in different seasons. However, the circulating insulin concentration seemed to be dependent on
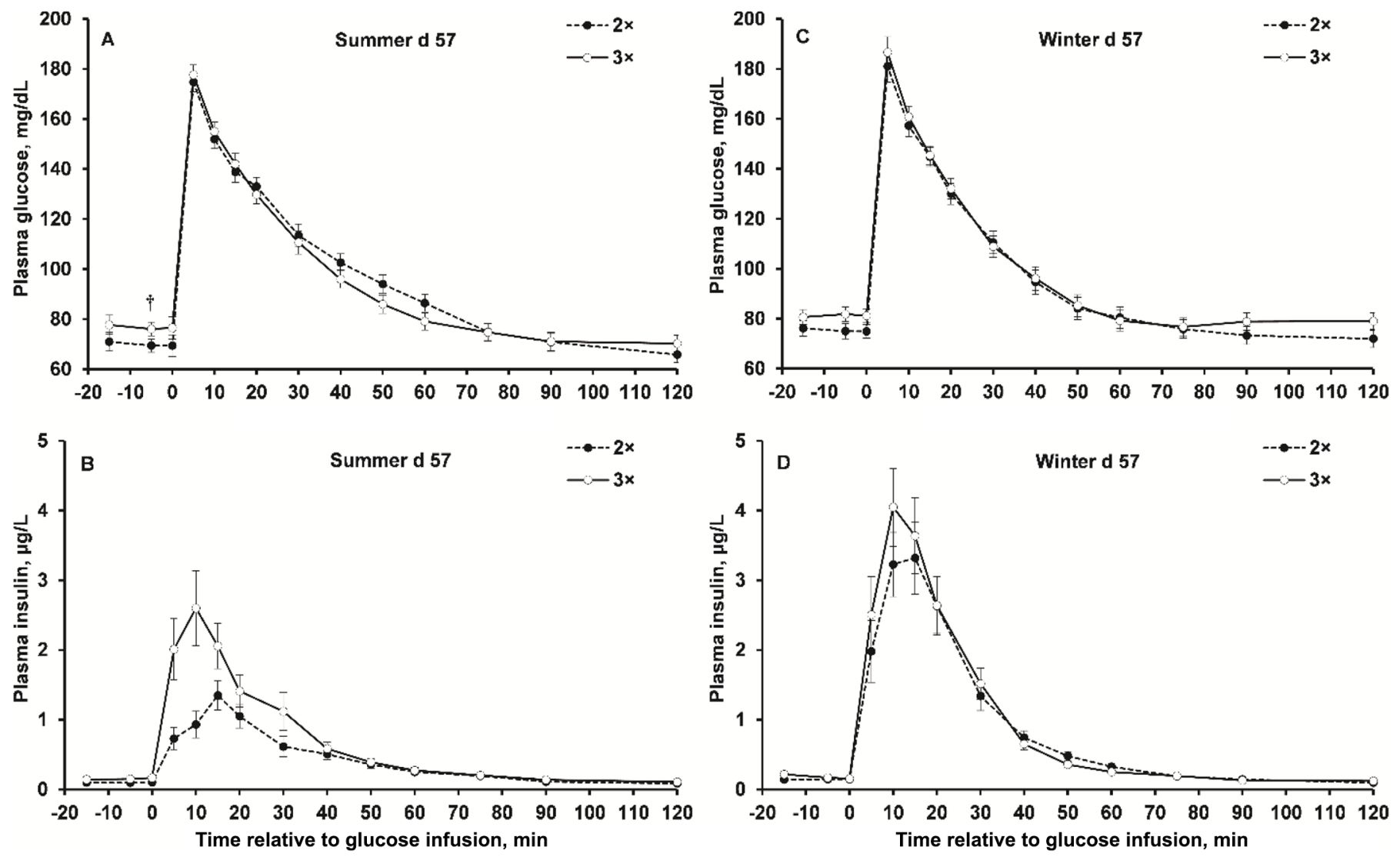

Figure 3. Effect of milk replacer feeding frequency [FF, twice $(2 \times, \mathrm{n}=16 /$ season $)$ versus 3 times $(3 \times, \mathrm{n}=16 /$ season $)$ per d] on plasma glucose and insulin concentrations during a glucose tolerance test performed on calves at $57.2 \pm 1.3 \mathrm{~d}$ of age during summer and $57.1 \pm 1.1 \mathrm{~d}$ of age during winter. Error bars represent SEM. During summer for the glucose concentration, effect of FF $(P=0.91)$ and FF by minute interaction $(P=0.10)$. During summer for the insulin concentration, effect of $\mathrm{FF}(P=0.04)$ and $\mathrm{FF}$ by minute interaction $(P=0.19)$. During winter for the glucose concentration, effect of FF $(P=0.52)$ and FF by minute interaction $(P=0.31)$. During winter for the insulin concentration, effect of FF $(P=0.73)$ and FF by minute interaction $(P=0.15) . \dagger P \leq 0.10$ 
Orellana Rivas et al.: MILK REPLACER FEEDING RATE AND FREQUENCY ON METABOLISM

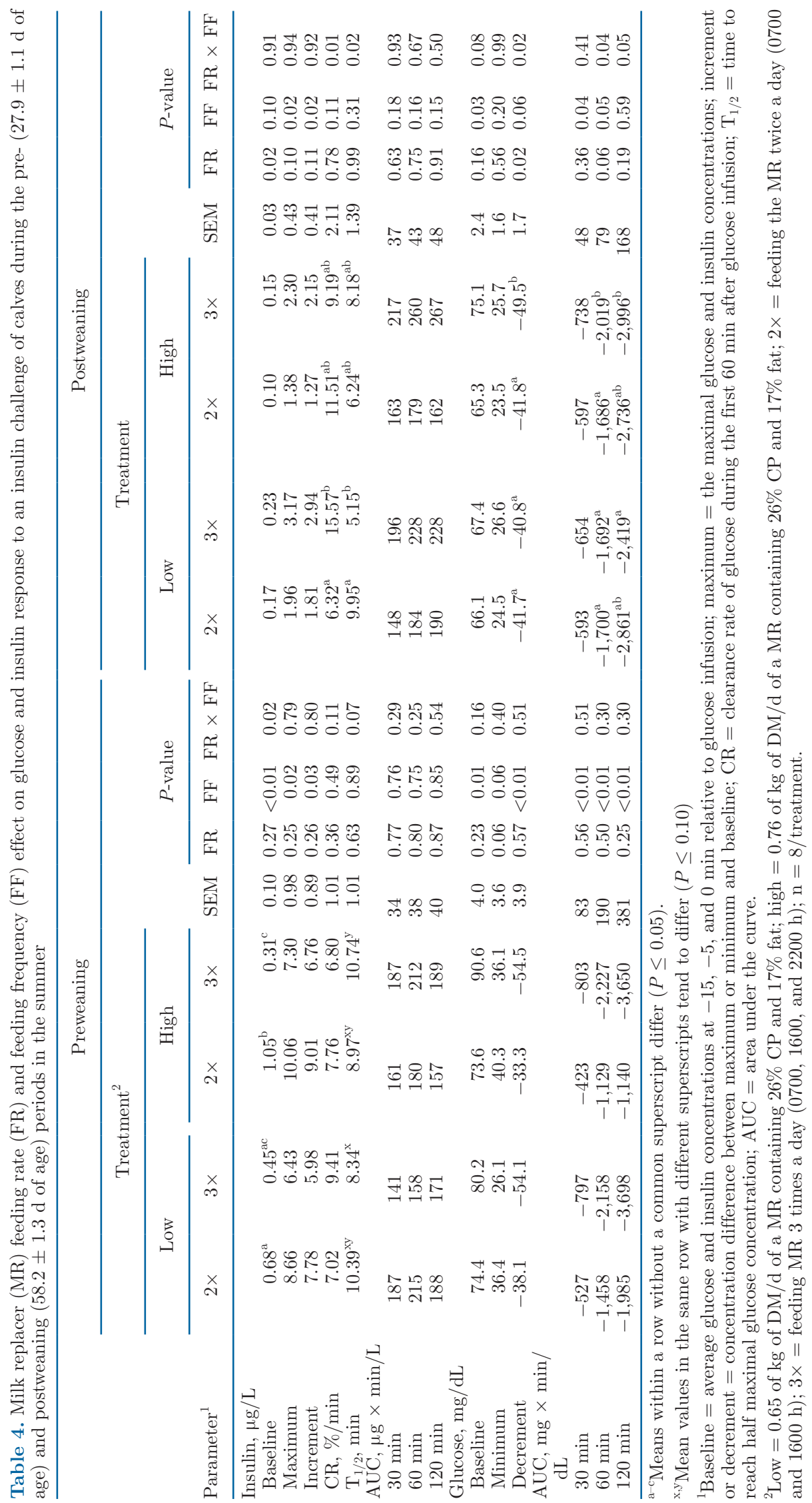




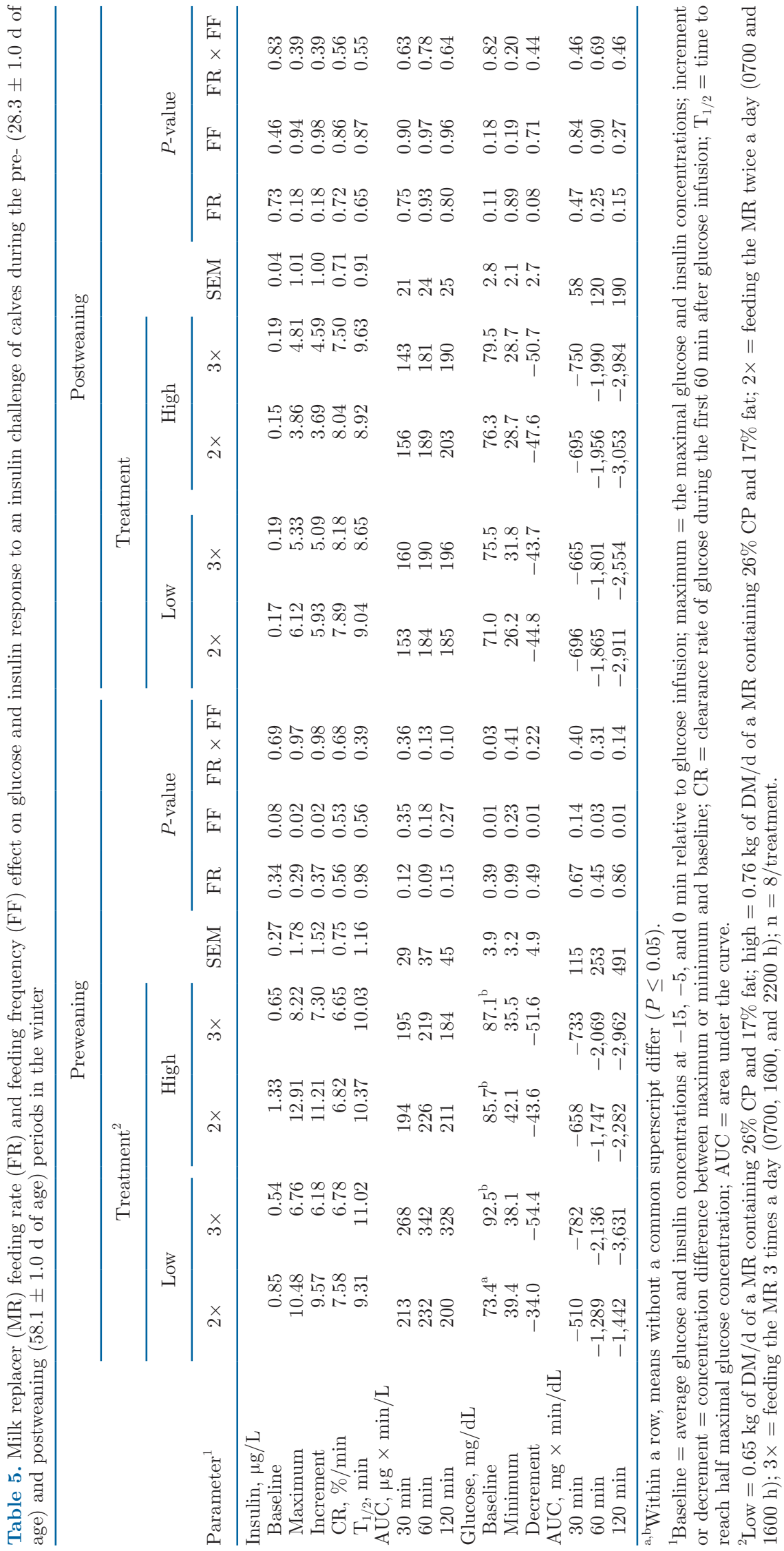


plasma glucose concentrations and reflected reduced insulin secretion in response to glucose stimulation of calves fed MR more frequently.

Peripheral tissue insulin response and pancreatic insulin release are critical components of glucose metabolism in dairy calves and are proposed to influence hepatic function, body growth and composition, and future performance (Gerrits et al., 2008; Van Eetvelde and Opsomer, 2017). It is imperative to consider if altered insulin action by nutrition or management in the preweaning period could persist after weaning. During summer, the greater glucose response after IC suggested that the increased peripheral tissue insulin response of calves fed MR $3 \times /$ d persisted after weaning compared with those fed $2 \times /$ d, especially for calves with greater MR FR. Following GTT after weaning, calves previously fed MR $3 \times / \mathrm{d}$ had greater insulin response compared with calves previously fed $2 \times / d$ in the summer. This contrasted with the observations with different FF before weaning and suggested that the pancreas might develop a compensatory response after the treat- ment ceased. The greater insulin release in response to glucose stimulation and stronger insulin response on peripheral tissues explains the faster glucose disposal after GTT of the postweaned calves previously fed MR more frequently during summer. Future research needs to examine the enhanced tissue insulin response by $\mathrm{FF}$ could persist beyond 8 wk of age, and how it would affect postweaning body growth, fat deposition, health, and future performance. In contrast, no difference in glucose or insulin responses were observed in the winter due to FF in both metabolic tests after weaning. These suggest that the altered metabolic response by increased FF diminished after the treatment ceased during winter. The mechanisms for altered peripheral tissue insulin response between calves with different FF only persisted after weaning in calves raised in summer is not clear but warrants further investigation.

In both seasons, FR had no effect on glucose or insulin response to either GTT or IC before or after weaning. In contrast, feeding larger quantities of MR at $2 \times / \mathrm{d}$ to veal calves caused hyperglycemia, hyperinsulinemia,
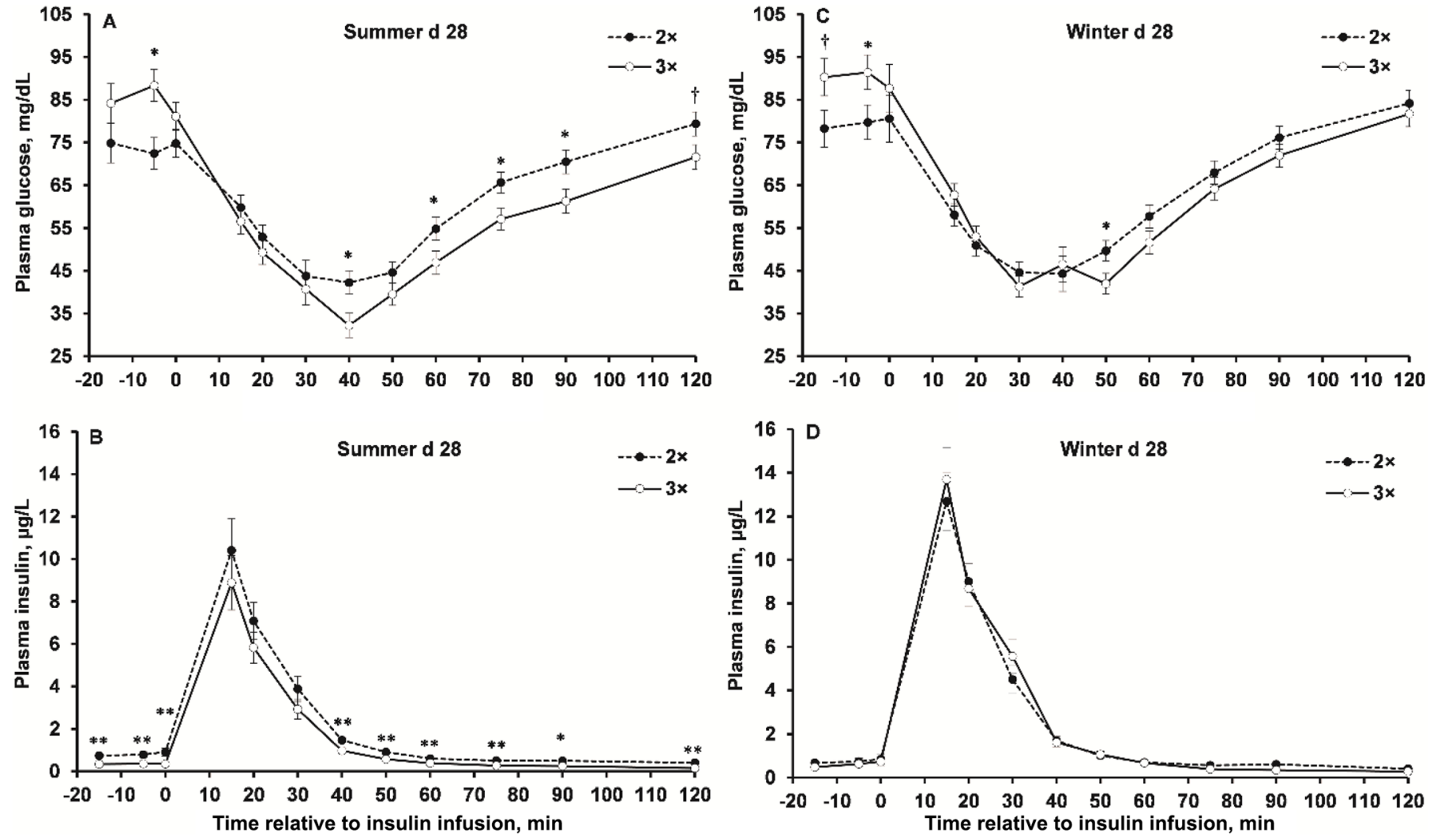

Figure 4. Effect of milk replacer feeding frequency [FF, twice $(2 \times, \mathrm{n}=16 /$ season $)$ versus 3 times $(3 \times, \mathrm{n}=16 /$ season $)$ per $\mathrm{d}]$ on plasma glucose and insulin concentrations during an insulin challenge performed on calves at $27.9 \pm 1.1 \mathrm{~d}$ of age during summer and $28.3 \pm 1.1 \mathrm{~d}$ of age during winter. Error bars represent SEM. During summer for the glucose concentration, effect of FF $(P=0.46)$ and FF by minute interaction $(P=0.01)$. During summer for the insulin concentration, effect of FF $(P<0.01)$ and FF by minute interaction $(P=0.01)$. During winter for the glucose concentration, effect of FF $(P=0.73)$ and FF by minute interaction $(P=0.02)$. During winter for the insulin concentration, effect of FF $(P=0.23)$ and FF by minute interaction $(P=0.17)$. ${ }^{* *} P \leq 0.01,{ }^{*} P \leq 0.05, \dagger P \leq 0.10$. 
and insulin resistance in peripheral tissues as a negative feedback mechanism of prolonged elevation of plasma insulin (Doppenberg and Palmquist, 1991; HostettlerAllen et al., 1994; Hugi et al., 1997). In preweaned dairy calves, increasing FR increased insulin response after GTT without affecting glucose clearance, suggesting insulin resistance (Bach et al., 2013b; Yunta et al., 2015; MacPherson et al., 2016). In this present experiment, no effect of FR was observed on pre- and postprandial glucose and insulin concentrations. In heavier veal calves, increasing FR of a MR containing $19.5 \%$ $\mathrm{CP}$ and $20.0 \%$ fat from 1.5 to $2.5 \times \mathrm{ME}$ requirements for maintenance increased preprandial insulin but not glucose concentrations, and substantially increased plasma glucose and insulin concentrations after feeding (Vicari et al., 2008). In preweaned dairy calves, feeding a MR containing $24 \% \mathrm{CP}$ and $18 \%$ fat at a rate of 1.2 $\mathrm{kg}$ of solids/d increased postprandial insulin responses but not glucose responses compared with those fed 0.6 $\mathrm{kg}$ of solids/d (MacPherson et al., 2016). The lack of differences in insulin secretion and glucose metabolism between calves with different FR in the current study may be due to the smaller differences in FR used in this study. Compared with previous studies where calves with higher FR consumed 1.5 to 2 times more MR than control animals (Bach et al., 2013b; Yunta et al., 2015; MacPherson et al., 2016), high calves only consumed $14 \%$ to $16 \%$ more MR than calves fed low. Our previous study (Orellana Rivas et al., 2020) reported that increasing FR more than high $2 \times / \mathrm{d}$ during summer in southern Georgia could lead to increased incidence of abomasum bloating. This prevented us from feeding an aggressive amount of MR ( $>0.76 \mathrm{~kg}$ of solids/d) to calves enrolled in this current study.

In conclusion, increasing MR FR from 0.65 to 0.76 $\mathrm{kg}$ of DM/d had no effect on glucose metabolism before or after weaning in both summer and winter. Regardless of the FR and season, feeding MR $3 \times / d$ reduced insulin secretion and improved insulin responses on peripheral tissues compared with $2 \times / d$ before weaning. In this current experiment, feeding high improved preweaning BW gain compared with low regardless of


Figure 5. Effect of milk replacer feeding frequency [FF, twice $(2 \times, \mathrm{n}=16 /$ season $)$ versus 3 times $(3 \times, \mathrm{n}=16 /$ season $)$ per $\mathrm{d}]$ on plasma glucose and insulin concentrations during an insulin challenge performed on calves at $57.9 \pm 1.1 \mathrm{~d}$ of age during summer and $58.1 \pm 1.1 \mathrm{~d}$ of age during winter. Error bars represent SEM. During summer for the glucose concentration, effect of FF $(P=0.04)$ and FF by minute interaction $(P=0.01)$. During summer for the insulin concentration, effect of FF $(P=0.17)$ and $\mathrm{FF}$ by minute interaction $(P=0.98)$. During winter for the glucose concentration, effect of FF $(P=0.06)$ and FF by minute interaction $(P=0.23)$. During winter for the insulin concentration, effect of FF $(P=0.11)$ and $\mathrm{FF}$ by minute interaction $(P=0.48)$. ${ }^{* *} P \leq 0.01,{ }^{*} P \leq 0.05, \dagger P \leq 0.10$. 
season, and feeding MR more frequently only improved preweaning BW gain during winter but not summer. The discrepancies between metabolic responses and growth performance suggest that altered insulin release and peripheral tissue insulin action may not significantly influence ADG. It is important to note that the methods (GTT and IC) used in this experiment can only assess the release and peripheral tissue response of insulin, but is unable to evaluate insulin sensitivity. Insulin sensitivity is determined by the insulin concentration to reach half of its maximal biological responses of an insulin-dependent tissue, and cannot be evaluated without assessing multiple insulin doses (De Koster and Opsomer, 2013). It is possible that altered insulin sensitivity has a greater effect on calf growth. Future research using hyperinsulinemic euglycemic clamp tests is needed to confirm the results obtained in this experiment and to evaluate the altered insulin sensitivity by MR FR and FF.

Changes in peripheral insulin responsiveness by $\mathrm{FF}$ in early life may also alter body composition of the growing animal, which have a significant implication on the cow's future performance. Indeed, Kaufhold et al. (2000) and Nussbaum et al. (2002) reported that veal and preruminant dairy calves fed MR more frequently had increased plasma IGF-I concentration. Circulating IGF-I concentration is strongly correlated with depositions of body protein and fat in preweaned Holstein calves (Bartlett et al., 2006). Interestingly, we observed a carryover effect of $\mathrm{FF}$ on peripheral tissue insulin response after weaning only during summer but not winter. It is important to examine if this carryover effect could persist in the calf's future life and its impact on subsequent reproductive and lactation performance.

\section{ACKNOWLEDGMENTS}

The authors thank the staff of the Dairy Research Center of the University of Georgia (Tifton) for animal care and data collection. The authors also thank Hannah Goodnight, Morgan Garrick, and Melissa Tawzer at the University of Georgia (Tifton) for their technical support. This project was supported by Georgia Agricultural Commodity Commission for Beef (Atlanta, GA), Milk Checkoff funded by Southeast Milk Inc. (Belleview, FL), and the National Institute of Food and Agriculture (Washington, DC) Hatch project (GEO00916). The authors declare no conflicts of interest.

\section{REFERENCES}

Bach, A., L. Domingo, C. Montoro, and M. Terré. 2013a. Short communication: Insulin responsiveness is affected by the level of milk replacer offered to young calves. J. Dairy Sci. 96:4634-4637. https: //doi.org/10.3168/jds.2012-6196.

Bach, A., M. Terré, and A. Pinto. 2013b. Performance and health responses of dairy calves offered different milk replacer allowances. J. Dairy Sci. 96:7790-7797. https://doi.org/10.3168/jds.2013-6909.

Bartlett, K. S., F. K. McKeith, M. J. VandeHaar, G. E. Dahl, and J. K. Drackley. 2006. Growth and body composition of dairy calves fed milk replacers containing different amounts of protein at two feeding rates. J. Anim. Sci. 84:1454-1467. https://doi.org/10 $.2527 / 2006.8461454 \mathrm{x}$.

Baumgard, L., and R. Rhoads. 2012. Ruminant Nutrition Symposium: Ruminant production and metabolic responses to heat stress. J. Anim. Sci. 90:1855-1865. https://doi.org/10.2527/jas.2011-4675.

Broucek, J., P. Kisac, and M. Uhrincat. 2009. Effect of hot temperatures on the hematological parameters, health and performance of calves. Int. J. Biometeorol. 53:201-208. https://doi.org/10.1007/ s00484-008-0204-1.

Chapman, C. E., P. S. Erickson, J. D. Quigley, T. M. Hill, H. G. Bateman II, F. X. Suarez-Mena, and R. L. Schlotterbeck. 2016. Effect of milk replacer program on calf performance and digestion of nutrients with age of the dairy calf. J. Dairy Sci. 99:2740-2747. https://doi.org/10.3168/jds.2015-10372.

Chavez, T. M. 2011. Adjusting milk replacer intake during heat stress and non-heat stress as a means of improving dairy calf performance. MS Thesis. Department of Animal Science, Texas A\&M University, College Station.

De Koster, J. D., and G. Opsomer. 2013. Insulin resistance in dairy cows. Vet. Clin. North Am. Food Anim. Pract. 29:299-322. https: //doi.org/10.1016/j.cvfa.2013.04.002.

Doppenberg, J., and D. Palmquist. 1991. Effect of dietary fat level on feed intake, growth, plasma metabolites and hormones of calves fed dry or liquid diets. Livest. Sci. 29:151-166. https://doi.org/10 .1016/0301-6226(91)90063-V.

Gebremedhin, K. G., C. O. Cramer, W. P. Porter, K. G. Gebremedhin, C. O. Cramer, and W. P. Porter. 1981. Predictions and measurement of heat production and food and water requirements of Holstein calves in different environments. Trans. ASAE 24:715-720. https://doi.org/10.13031/2013.34326.

Gerrits, W. J. J., J. J. G. C. Van Den Borne, and J. W. Blum. 2008. Low-dietary protein intake induces problems with glucose homeostasis and results in hepatic steatosis in heavy milk-fed calves. Domest. Anim. Endocrinol. 35:121-129. https://doi.org/10.1016/j .domaniend.2007.10.002.

Hayirli, A., D. R. Bremmer, S. J. Bertics, M. T. Socha, and R. R. Grummer. 2001. Effect of chromium supplementation on production and metabolic parameters in periparturient dairy cows. J. Dairy Sci. 84:1218-1230. https://doi.org/10.3168/jds.S0022 -0302(01)74583-3.

Hill, T. M., J. D. Quigley, F. X. Suarez-Mena, H. G. Bateman, and R. L. Schlotterbeck. 2016. Effect of milk replacer feeding rate and functional fatty acids on dairy calf performance and digestion of nutrients. J. Dairy Sci. 99:6352-6361. https://doi.org/10.3168/jds .2015-10812.

Hostettler-Allen, R. L., L. Tappy, and J. W. Blum. 1994. Insulin resistance, hyperglycemia, and glucosuria in intensively milk-fed calves. J. Anim. Sci. 72:160-173. https://doi.org/10.2527/1994.721160x.

Hugi, D., R. M. Bruckmaier, and J. W. Blum. 1997. Insulin resistance, hyperglycemia, glucosuria, and galactosuria in intensively milkfed calves: dependency on age and effects of high lactose intake. J. Anim. Sci. 75:469-482. https://doi.org/10.2527/1997.752469x.

Kaufhold, J. N., H. M. Hammon, R. M. Bruckmaier, B. H. Breier, and J. W. Blum. 2000. Postprandial metabolism and endocrine status in veal calves fed at different feeding frequencies. J. Dairy Sci. 83:2480-2490. https://doi.org/10.3168/jds.S0022-0302(00)75140 $-\mathrm{X}$.

Littell, R. C., P. R. Henry, and C. B. Ammerman. 1998. Statistical analysis of repeated measures data using SAS procedures. J Anim. Sci. 76:1216-1231. https://doi.org/10.2527/1998.7641216x.

MacPherson, J., S. J. Meale, K. Macmillan, J. Haisan, C. J. Bench, M. Oba, and M. A. Steele. 2019. Effects of feeding frequency of an elevated plane of milk replacer and calf age on behavior, and glucose 
and insulin kinetics in male Holstein calves. Animal 13:1385-1393. https://doi.org/10.1017/S175173111800294X.

MacPherson, J. A. R., H. Berends, L. N. Leal, J. P. Cant, J. MartinTereso, and M. A. Steele. 2016. Effect of plane of milk replacer intake and age on glucose and insulin kinetics and abomasal emptying in female Holstein Friesian dairy calves fed twice daily. J. Dairy Sci. 99:8007-8017. https://doi.org/10.3168/jds.2015-10826.

Monteiro, A. P. A., J. R. Guo, X. S. Weng, B. M. Ahmed, M. J. Hayen, G. E. Dahl, J. K. Bernard, and S. Tao. 2016. Effect of maternal heat stress during the dry period on growth and metabolism of calves. J. Dairy Sci. 99:3896-3907. https://doi.org/10.3168/jds .2015-10699.

Nussbaum, A., G. Schiessler, H. M. Hammon, and J. W. Blum. 2002. Growth performance and metabolic and endocrine traits in calves pair-fed by bucket or by automate starting in the neonatal period. J. Anim. Sci. 80:1545-1555. https://doi.org/10.2527/2002 $.8061545 \mathrm{x}$

Orellana Rivas, R. M., G. H. Komori, V. V. Beihling, T. N. Marins, J. K. Bernard, and S. Tao. 2020. Effects of milk replacer feeding levels on performance and metabolism of preweaned dairy calves during summer. J. Dairy Sci. 103:313-324. https://doi.org/10.3168/ jds.2019-17360.

Orellana Rivas, R. M., T. Rodrigues, J. da Silveira E. Sousa, and V. H. L. R. Melo., JGao, D., J. Ferreira de Araújo, T. N. Goncalves de Souza, P. Marins, J. K. Melendez, Bernard, and S. Tao. 2022. Effects of milk replacer feeding rate and frequency of preweaning dairy calves in the southeastern United States: Performance, abomasal emptying, and nutrient digestibility. J. Dairy Sci. 105:1150-1169. https://doi.org/10.3168/jds.2021-20287.

Orellana Rivas, R. M., and S. Tao. 2021. Orellana Rivas et al. 2022 Supplementary calf 2018 metabolism. https://doi.org/http://doi .org/10.5281/zenodo.4613068.
Stanley, C. C., C. C. Williams, B. F. Jenny, J. M. Fernandez, H. G. Bateman II, W. A. Nipper, J. C. Lovejoy, D. T. Gantt, and G. E. Goodier. 2002. Effects of feeding milk replacer once versus twice daily on glucose metabolism in Holstein and Jersey calves. J. Dairy Sci. 85:2335-2343. https://doi.org/10.3168/jds.S0022 $-0302(02) 74313-0$.

Stull, C. L., L. L. M. V. Messam, C. A. Collar, N. G. Peterson, A. R. Castillo, B. A. Reed, K. L. Andersen, and W. R. VerBoort. 2008. Precipitation and temperature effects on mortality and lactation parameters of dairy cattle in California. J. Dairy Sci. 91:45794591. https://doi.org/10.3168/jds.2008-1215.

Tao, S., A. P. A. Monteiro, M. J. Hayen, and G. E. Dahl. 2014. Short communication: Maternal heat stress during the dry period alters whole body insulin response of calves postnatally. J. Dairy Sci. 97:897-901. https://doi.org/10.3168/jds.2013-7323.

Van Eetvelde, M., and G. Opsomer. 2017. Innovative look at dairy heifer rearing: Effect of prenatal and post-natal environment on later performance. Reprod. Domest. Anim. 52:30-36. https://doi .org/10.1111/rda.13019.

Vicari, T., J. J. G. C. van den Borne, W. J. J. Gerrits, Y. Zbinden, and J. W. Blum. 2008. Postprandial blood hormone and metabolite concentrations influenced by feeding frequency and feeding level in veal calves. Domest. Anim. Endocrinol. 34:74-88. https://doi.org/ 10.1016/j.domaniend.2006.11.002.

Yunta, C., M. Terré, and A. Bach. 2015. Short- and medium-term changes in performance and metabolism of dairy calves offered different amounts of milk replacers. Livest. Sci. 181:249-255. https:/ /doi.org/10.1016/j.livsci.2015.09.008. 